\title{
A Systematic Review: Topical Sucralfate for Burn Wound
}

\author{
Loelita Lumintang*(i), Made S. Adnyana, I. Nyoman Putu Riasa, Anak Agung Gde Ngurah Asmarajaya, Agus Roy Hamid, \\ Hendra Sanjaya \\ Department of Surgery, Division of Plastic Reconstructive and Aesthetic Surgery, Faculty of Medicine, Udayana University, \\ Sanglah General Hospital, Denpasar, Bali, Indonesia
}

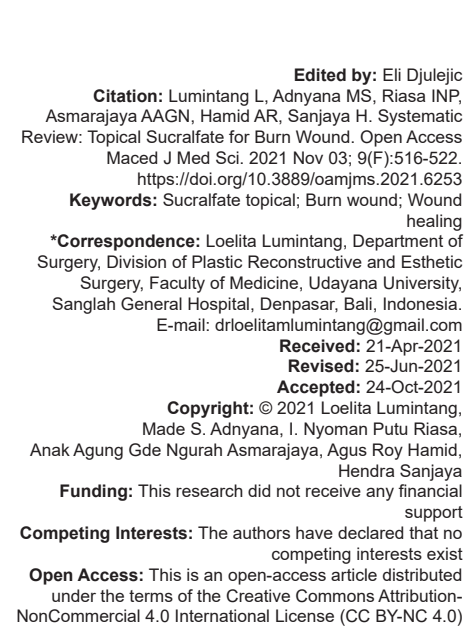

Introduction

Burn is one of the most severe injuries with high mortality and morbidity. Burns are dynamic injuries that can change into deeper injuries over time [1]. Deep burns require prolonged healing time often result in significant scarring and contractures [2]. It's a distressful experience not only for the burn victims, but also for their families. Every year, more than $10,00,000$ people in the developing countries suffer from moderate to severe burn injuries [3]. In a developing country such as Indonesia, where there is a very high incidence of burns with limited resources available for their management, surgical means of wound management such as tangential excision is not always feasible. The most of our patients are managed by a staged surgical. Wound closure for topical wound therapy and dressing remain the mainstay of treatment [4]. The multiplicity of systemic and topical regime in use is an indication that none is completely satisfactory [5], [6], [7], [8]. Topical therapy coupled with other measures has proved to be the mainstay of treatment [9], [10].
Silver nitrate, sulfamylon, and a combination of a sulfonamide and silvers sulfadiazine (SSD) are the topical antimicrobial agents in the burn wound dressings [11], [12] SSD is the most common topical agent for partial thickness burns; it is preferred to other medications such as mafenide acetate and silver nitrate, but in our center only SSD is available. We use sucralfate, it based on expert opinion (level evidence VI) for topical agent dressing in $2^{\text {nd }}$ degree wound. SSD is a very effective bactericidal agent, active against most Germ-positive and Germnegative bacteria, but causes systemic side effects such as neutropenia, crystalluria, erythema multiforme, and methemoglobinemia [11], [12], [13]. Moreover, more recent studies have reported that healing of partial thickness burns is delayed by SSD because it impairs fibroblasts and epithelial proliferation [8], [14], [15], [16]. Hence, we try to find out rather sucralfate can replace the others topical agent, including SSD and be a better choice for burn wound or not.

Sucralfate, a basic complex salt of sucrose octasulfate and aluminum hydroxide, is used as an effective mucoprotective agent since early eighties in the treatment of peptic ulcers [17]. Topical sucralfate has been used in the treatment of resistant perineal 
and peristomal excoriation. The initial work by Hayashi et al., [18] the use continues for stomatitis, decubitus ulcers, as well as radiation proctitis.

Various recent sporadic studies have demonstrated the safety and efficacy of topical sucralfate in skin protection and wound repair by accelerating cell proliferation in the skin layers leading to clear thickening of the epidermis and dermis [18], [19], [20], [21]. The clinical observations also have supported the antiinflammatory, bacteriostatic, and decreasing pain properties of sucralfate [20], [21], [22]. It works by binding to basic fibroblast growth factor (bFGF) and increasing their concentration in the wound [23].

Several systematic reviews have examined the effectiveness of topical agent for burn wounds [24], [25], [26], [27]. However, none of these reviews specifically discussed of the efficacy of topical sucralfate in burn wounds. Thus, the aim of the current systematic review study was to determine the efficacy of topical sucralfate in burn wound healing.

\section{Materials and Methods}

The following databases were searched for relevant studies: Google Scholar, PUBMED, and Proquest. Data sources were searched using MeSH terms: "topical sucralfate" and "burn wound" for all publications up to December 2018. All paper that written English were included in the study.

The searches were limited to humans and a filter was applied to identify comparing studies, controlled clinical trials, and randomized controlled trials (RCTs) in all databases as described elsewhere [28]. For the search strategy, the medical subject headings "topical sucralfate" AND "burn" OR "burn wound" were used. Patient, intervention, comparison, and outcome also method applied to select appropriate journals for the review process. These criteria were elaborated as follow: (1) patient: subject with grade two of burn wound or above, (2) intervention: sucralfate as topical agent, comparison: topical agent beside sucralfate, and outcome: healing time. To ensure that the search was comprehensive, the reference lists of the retrieved articles and any identified review articles were reviewed. In addition, the corresponding authors of identified studies were contacted, and experts working in the field of burn therapy or sucralfate, were asked for further studies. RCTs involving topical sucralfate for burn wound healing were included. No restriction on date, and publication type of the studies was applied. The relevant data were extracted by two reviewers and methodological quality was assessed using the Cochrane criteria for risk of bias assessment [29]. Any disagreements between the two reviewers were resolved through discussion.
The first search of the literature was undertaken by one investigator (L.M.) under supervision of the principal investigator (P.R.), who is a content expert. Following exclusion of non-relevant trials, assessment of eligibility of the remaining publications was performed. Two independent reviewers (N.A., S.A) examined the list of titles and identified potentially relevant articles. In cases where there was disagreement as to the relevance of a study, an attempt to reach a consensus was made through discussion and by reviewing the study's abstract or full article. A third reviewer (P.R.) was available to make a final decision if necessary.

Several foreign-language publications were found, but only papers written in English were included. The literature search involved articles published up to December 2018. All RCTs, clinical controlled trials and observational comparative studies were included. No restrictions on publication date or status were made. Eligible studies needed to report on topics related to plastic and reconstructive surgery and the trial authors needed to report at least one clinical end point. This systematic review only included (1) RCTs which fulfilled the current standard definition for this study design (also named true RCTs), (2) non-RCTs, (3) comparative studies, and (4) cohort studies regarding humans.

The quality of all RCTs is evaluated using Jadad score [30]. Those articles were assessed for randomization, double blinding, and withdrawals/ dropouts. Total score ranged from 0 to 5 , with 0 as the lowest score and 5 as the highest score.

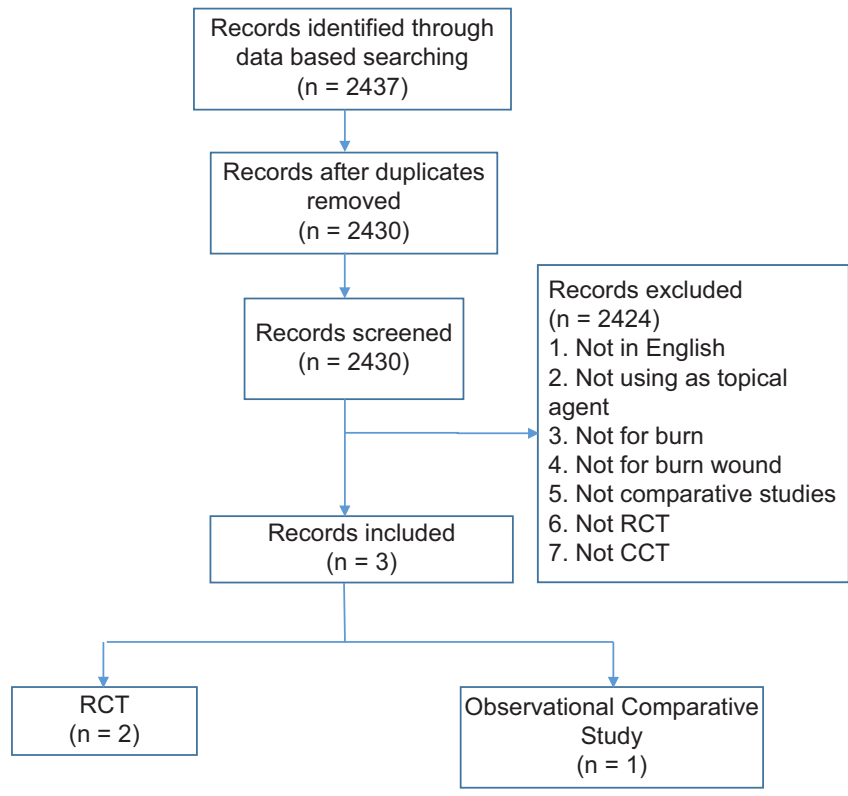

Figure 1: PRISMA flow chart of study search and inclusion

\section{Data analysis}

Trials were only included if they measured the healing time for burn as the primary outcomes. Measures such as pain, infection rate, and adverse events were the secondary outcomes. 
Table 1: Assessment risk of bias using Jadad score [28]

\begin{tabular}{|c|c|c|c|c|c|c|c|}
\hline \multirow[t]{2}{*}{ No } & \multirow[t]{2}{*}{ Study } & \multicolumn{5}{|l|}{ Jadad score } & \multirow[t]{2}{*}{ Total } \\
\hline & & Randomised & $\begin{array}{l}\text { Double } \\
\text { Blind }\end{array}$ & $\begin{array}{l}\text { Withdrawals/ } \\
\text { Dropouts }\end{array}$ & $\begin{array}{l}-1 \text { if use innapropiate } \\
\text { use of randomization }\end{array}$ & $\begin{array}{l}-1 \text { if use innapropiate } \\
\text { method of blinding }\end{array}$ & \\
\hline 1 & $\begin{array}{l}\text { Anjana } \\
\text { et al., } 2001\end{array}$ & +1 & +1 & +1 & 0 & 0 & 3 \\
\hline 2 & $\begin{array}{l}\text { Godhi et al., } \\
2017\end{array}$ & 0 & +1 & +1 & 0 & 0 & 2 \\
\hline
\end{tabular}

Table 2: Overview of studies on wound healing

\begin{tabular}{|c|c|c|c|c|c|}
\hline Authors & Design & $\mathrm{n}$ & Comparison & Results in relation to the sucralfate topical group & Statistical Result, P value \\
\hline Banati et al., 2001 [31] & RCT & 60 & $\begin{array}{l}\text { Effects of Sucralfate Cream and } \\
\text { other topical antimicrobial agents } \\
\text { on second and third degree } \\
\text { burns }\end{array}$ & $\begin{array}{l}\text { Rates of healing was statistically significant } \\
\text { Rapid epithelialisation of second degree burns with } \\
\text { minimal said effect }\end{array}$ & $\begin{array}{l}\text { First Trial: } P=0.00001 \\
\text { Second Trial } P=0.00067\end{array}$ \\
\hline Godhi et al., 2017 [32] & $\mathrm{RCT}$ & 60 & $\begin{array}{l}\text { Effects of Silver sulfadiazine } 1 \% \\
\text { and Topical Sucralfate on second } \\
\text { degree superficial burns }\end{array}$ & $\begin{array}{l}\text { Topical sucralfate dressing is efficacious in terms of } \\
\text { development of early granulation in the healing of } \\
\text { second-degree superficial burns compared to silver } \\
\text { sulfadiazine (SSD) dressing }\end{array}$ & $p>0.050$ \\
\hline Koshariya et al., 2018 [33] & Observational study & 50 & $\begin{array}{l}\text { Effects of Silver sulfadiazine 1\% } \\
\text { and Topical Sucralfate on burn } \\
\text { wounds healing }\end{array}$ & $\begin{array}{l}\text { Faster healing by re-epithelialization was present in } \\
\text { sucralfate group } \\
\text { Incidence of secondary infection was less when } \\
\text { topical sucralfate } \\
\text { More wounds was healed in sucralfate group as } \\
\text { compared with in SSD group } \\
\text { A marked relief in pain and discomfort after } \\
\text { sucralfate application as compared to SSD }\end{array}$ & $\begin{array}{l}\text { Faster Healing was present } \\
\text { in group one (sucralfate): } \\
11-22 \text { days } \\
\text { Incidence of secondary } \\
\text { infection: } \\
\text { Group } 1=255 \\
\text { Group } 2, a=16.6 \% \\
\text { Group } 2, b=66,66 \%\end{array}$ \\
\hline
\end{tabular}

\section{Results}

The flow of searches, and number of trials identified and included in this study are shown in Figure 1. Of the 2430 records identified, 2426 studies were excluded for reasons as stated in the methods.

Finally, 2 RCTs were eligible for the analysis and quality of these studies were analyzed using Jadad score (Table 1). Total score varied from 1-3. None of them had full score due to lack of description on randomization method, blinding, and dropouts.

\section{Description of Studies}

A total of four trials were included with a total of 250 patients with a variety of burn wounds (Table 2). One study in 2001 [31] included sixty patients conducted in two phase of trials, in the first phase thirty participants of whom were treated with sucralfate cream while the other 30 participants were treated with other topical antimicrobial agents. Twentyone and nine patients in the study had second-degree burns and third degree burns, respectively. In the second phase, a double blind study was carried out on 25 patients where one area of burns was treated with sucralfate cream while another control area of the same patient was treated with a placebo ointment. The period of epithelialization of the study group treated with sucralfate cream was 18.8 days compared with 24.6 days with other topical agents $(p=0.00001)$. In the double-blind study, it also found that burn healing in the areas treated with sucralfate was fasterthan those treated with blind placebo ointment ( $p=0.00067)$. Histopathological studies were also carried out, and they showed that sucralfate cream promoted rapid epithelialization.

Another one year RCT [32] has total of 60 patients with $<50 \%$ second degree superficial burns who were divided into two groups. Group A were treated with topical sucralfate and group B were treated with $1 \%$ silver sulfadiazine dressing. $50 \%$ patients in the group $A$ had the granulation appeared in less than 7 days, whereas $56,67 \%$ patients in the group $B$ had granulation appeared between 15 and 20 days $(p=0.149)$. The mean day of granulation $p=0.396)$ and the wound culture on day 1,7 and 14 ( $p>0.050)$ were not significantly different.

Department of General Surgery, Hamidia Hospital Bhopal [33] divided 50 patients deep burn injury into group one (sucralfate) and group two [a-sucralfate; b-silver sulfadiazine (SSD)]. The demographics, history, physical, and systemic examinations of the patients were recorded. Granulation tissue for group one (in 6-17 days) as compared to SSD (14-22 days). It was noticed that faster healing by re-epithelialization was present in group one (11-22 days) as compared with SSD group (15-30 days). By the end of $3^{\text {rd }}$ week $50-75 \%$ of wound was healed in group one as compared with $35-50 \%$ in group two. Incidence of secondary infection was less when topical sucralfate was used (group one $=25 \%$; group two: $a=16 b=66.66 \%$ ). Secondary outcome measures such as pain, discomfort, and the adverse effect of interventions were reported in this study. There was a marked relief in pain and discomfort after sucralfate application as compared to SSD. 
Risk of Bias Assessment in Included Trials

The risk of bias of the included studies is summarized in Figure 2. The majority of the trials had unclear risk of bias for sequence generation and concealment of allocation. There was no loss to follow-up in any of the included in the studies.

All trials were judged to have low risk of bias. For the domain "selective outcome reporting" when outcomes measures specified in the methods section were also reported in the results.

\section{Discussion}

The definition of burns by the World Health Organization [34] is "an injury to the skin or other organic tissue primarily caused by heat, radiation, radioactivity, electricity, friction, or contact with chemicals." The severity of burn injuries depends on the depth of the wound injury, the depth progressiveness and the extent of the body area affected. Burn wounds are also susceptible to infection because their moist environment provides an ideal situation for bacteria to multiply [35]. Infection by microorganisms is a major cause of morbidity associated with extended hospital stay and high medical costs [36]. The prevention of infection is an important factor in the acceleration of healing and reduction of morbidity [34].

In Burn patient, wound closure with topical therapy and dressing remain the mainstay of treatment. Various types of topical therapy and dressing have been used in the treatment of burn injuries. The basic purpose is to expedite the epithelial healing and to prevent the formation of abnormal scar. Meanwhile, SSD may be considered as the gold standard for topical burn treatment [37]. However, data from animal studies and human trials suggests that silver delays wound healing as it is toxic to regenerating keratinocytes [38], [39], [40], [41], [42]. In addition, in a systematic review published in 2012, Aziz et al. [43] reported that when silver was compared to non-silver dressings, silver was shown to worsen healing time. However, silver is still used as a comparator or control in many burn trials because it is considered as the gold standard in the treatment of burn wounds [37], [41], [44].

Initially, Hollander et al. [45] was the first who discovered that oral sucralfate is able to protect the gastric mucosa from injury by ethanol. More studies show same evidence; for superficial or partial thickness wounds, sucralfate topical was found to have statistically significant beneficial effects compared to another topical agents for the outcomes time to complete wound healing, proportion of wounds completely healed, and proportion of infected wounds rendered sterile in burn wound [21], [45]. Sucralfate acts by increasing both bFGF and eGF concentration in the wound tissue. It

\begin{tabular}{|c|c|c|c|c|c|c|c|}
\hline & $\begin{array}{l}\text { Random } \\
\text { sequence } \\
\text { generation } \\
\text { (selection } \\
\text { bias) }\end{array}$ & $\begin{array}{l}\text { Allocation } \\
\text { concealment } \\
\text { (selection } \\
\text { bias) }\end{array}$ & $\begin{array}{l}\text { Blinding of } \\
\text { participants } \\
\text { and } \\
\text { personnel } \\
\text { (performance } \\
\text { bias) }\end{array}$ & $\begin{array}{l}\text { Blinding } \\
\text { of } \\
\text { outcome } \\
\text { assessment } \\
\text { (detection } \\
\text { bias) }\end{array}$ & $\begin{array}{l}\text { Incomplete } \\
\text { outcome } \\
\text { data } \\
\text { (attrition } \\
\text { bias) }\end{array}$ & $\begin{array}{l}\text { Selective } \\
\text { reporting } \\
\text { (reporting } \\
\text { bias) }\end{array}$ & $\begin{array}{l}\text { Other } \\
\text { bias }\end{array}$ \\
\hline $\begin{array}{l}\text { Anjana } \\
\text { Banati et al., } \\
2001^{1}\end{array}$ & & & & & & & \\
\hline $\begin{array}{l}\text { Godhi As et } \\
\text { al., } 2017^{3}\end{array}$ & & & & & & & \\
\hline $\begin{array}{l}\text { Mahim } \\
\text { Koshariya et } \\
\text { al., } 2018^{4}\end{array}$ & & & & & & & \\
\hline
\end{tabular}

Note: $\begin{aligned} & \square \\ & \begin{array}{l}\text { Indicates unclear risk of bias } \\ \text { Indicates low risk of bias } \\ \text { Indicates high risk of bias }\end{array}\end{aligned}$

Figure 2: Risk of bias summary 
also inhibits the release of interleukin-2, interferon gamma, and cytokines from the burnt damaged skin cells and thus prevents inflammation and produces soothing effect [21]. Moreover, it does not have any adverse effects [45].

The sucralfate's advantages can be summarized by its cost effectiveness, no systematic side effect has been reported, In developing country, it has been covered by government insurance and or easy to get, It help to moist the wound, decreasing pain, The most needed abilities that sucralfate has for burn wound are, its bacteriostatic effect, anti-inflammatory effect, epithelialization stimulation, and increasing mount of bFGF. It is better than SSD in wound healing rate, decreased infection rate and enhancement of epithelialization with no local or systemic adverse reactions.

In this systematic review, it is difficult to judge the quality of the evidence as the majority of the domains in the risk of bias assessment were inadequately described. Although blinding of participants and care providers was difficult, the trial investigators could have blinded the outcome assessors to reduce the risk of outcome bias.

The results of this review are in agreement with other reviews examining evidence of effectiveness of sucralfate topical for wound healing [26], [27].

The result of this curent review provided higher level of evidence-based references for the application of topical agents in burn wounds. Acording to the best of our knowledge, the evidences for the use of topical agents only limited on the level of VI (expert opinion). Hence, this study presented stronger scientific evidences for topical agents application in clinical practices for improving the healing time of burn wound.

This review had some limitations. We only reviewed a limited number of RCTs and multicentres studies in the current study. Beside that, this review also presented heterogenous type of errors and causes of burn wounds and unclear frequency of topical agent application. Therefore, future study required to involve more RCT-designed study with more specific criteria of burn wound and its therapy to provide a higher-level of scientific evidence of the topical agent application.

\section{Conclusions}

Current systematic review strongly suggests that topical sucralfate possesses a beneficial effect for second degree of burn wound healing. Despite a positive finding favoring topical sucralfate when compared to other topical agent, the scarcity of highquality evidence to justify routine use of sucralfate topical for burn wound healing in clinical practice is highlighted in this review, and this study was limited to second-degree burns and may not be generalized in all the burn injuries. Multicenter RCT with larger sample size of using sucralfate in $2^{\text {nd }}$ degree burn wound are needed to make recommendation for burn wound treatment guideline.

Authors of future trials should use common and clinically relevant end points to assess the effectiveness of sucralfate topical, and to use the Consolidated Standards of Reporting Trial statement to improve the quality of reporting of trials.

\section{References}

1. Singer AJ, McClain SA. The effects of a high potency topical steroid on cutaneous healing of burns in Pigs. Acad Emerg Med. 2002;9(10):977-82. 10.1111/j.1553-2712.2002.tb02128.x PMid:12359532

2. Singer AJ, Taira BR, Lin F, Lim T, Anderson R, McClain SA et al. Curcumin reduces injury progression in a rat comb burn model. J Burn Care Res. 2011;32:135-42. 10.1097/ BCR.0b013e318203337b

PMid:21088615

3. Jahangir S, Rehman M, Munir MK. Identification and drug susceptibility pattern of pathogenic bacterial species among burn patients. Pak J Med Health Sci. 2017;11:698-702.

4. Chen RW. Biochemistry of wound healing monograph. Surg Sci. 1964;1:215.

5. Hassanzadeh G, Mehdikanloo N. The effect of compound of Brsssica oleracea L. and Egg White on burn wound healing in rat. Asrar Sabzevar School Med Scien. 2004;11(4):6-12.

6. Nascimento EG, Sampaio TB, Medeiros AC, Azevedo EP. Evaluation of Chitosam gel with 17. Silver Sulfadiazine as an alternative for laurn wound treatment inrats. Acta Cir Bras. 2009;24(6):460-5. 10.1590/s0102-86502009000600007 PMid:20011831

7. Williams FN, Herndon DN, Hawkins HK, Lee Jo, Cox RA, Kulp GA, et al. The leading causes of death after burn injury in a single pediatric burn center. Crit Care. 2009;13(6):R183. $10.1186 /$ cc8170

PMid:19919684

8. DeSanti L. Pathophysiology and current management of burn injury. Adv Skin Wound Care. 2005;18(6):323-32; quiz 332-4. 10.1097/00129334-200507000-00013 PMid:16096398

9. Kahn SA, Beers RJ, Lentz CW. Resuscitation after severe burn injury using high dose ascorbic acid: A retrospective review. J Burn Care Res. 2011;32(1):110-7. 10.1097/ BCR.0b013e318204b336 PMid:21131846

10. Zakine G, Barbier V, Garcia-Fillipe S, Luboinski J, PapyGarcia D, Chachques JC, et al. Matrix therapy with RGTA OTR 4120 improves healing time and quality in hairless rats with deep second degree burns. Plast Reconst Surg. 2011;127:54150. 10.1097/PRS.0b013e318200a910

PMid:21285759

11. Beheshti A, Shafigh $Y$, Zangivand AA, Samiee-Rad $F$, Hassanzadeh G, Shafigh N. Comparison of topical sucralfate and silver sulfadiazine cream in second degree burns in rats. 
Adv Clin Exp Med. 2013;22(4):481-7.

PMid:23986207

12. Gregory SR, Piccolo N, Piccolo MT, Piccolo MS, Heggers JP. Comparison of propolisskin cream to silver sulfadiazine: A naturopathic alternative to antibioticsin treatment of minor burns. Jaltern Complement Med. 2002;8(1):77-83. 10.1089/107555302753507203

PMid: 11890438

13. Hoşnuter $M$, Gürel $A$, Babucçu $O$, Armutcu $F$, Kargi $E$, Işikdemir A. The effect of CAPE on lipid peroxidation and nitricoxide levels in the plasma of rats following thermal injury. Burns. 2004;30(2):121-5. 10.1016/j.burns.2003.09.022 PMid:15019118

14. Lee AR, Moon HK. Effect of topically applied silver sulfadiazine on fibroblast cell proliferation and biomechanical properties of the wound. Arch Pharm Res. 2003;26(10):855-60. 10.1007/ BF02980032

PMid: 14609135

15. Stern HS. Silver sulphadiazine and the healing of partial thickness burns: A prospective clinical trial. $\mathrm{Br} \mathrm{J}$ Plast Surg. 1989;42(5):581-5. 10.1016/0007-1226(89)90050-7 PMid:2679953

16. Atiyeh BS, Costagliola M, Hayek SN, Dibo S. Effect of Silver on burn wound infection Control and healing: Review of the literature. Burns. 2007;33(2):139-48. 10.1016/j.burns.2006.06.010 PMid:17137719

17. Nagashima R. Development and characteristic of sucralfate. J Clin Gastroenterol. 1981;3(Suppl 2):103-10. PMid:6798099

18. Hayashi AH, Lau HY, Gillis DA. Topical sucralfate-effective therapy for management of resistant peristomal and perineal excoriation. J Paediatr Surg. 1991;26(11):1279-81. 10.1016/0022-3468(91)90598-n

PMid:1812256

19. Banati A, Chowdhury SR, Mazumder S. Topical use of sucralfate cream in second and third degree burns. Burns. 2001;27(5):4659. $10.1016 / \mathrm{s} 0305-4179(00) 00165-0$

PMid:11451599

20. Tumino G, Masuelli L, Bei R, Simonelli L, Santoro A Francipane $\mathrm{S}$. Topical treatment of chronic venous ulcers with sucralfate: A placebo controlled randomized study. Int J Mol Med. 2008;22(1):17-23.

PMid: 18575771

21. Burch RM, Millan BA. Sucralfate induces proliferation of dermal fibroblasts and keratinocytes in culture and granulation tissue formation in full thickness skin wound. Agents Action 1991;34(2):229-31. 10.1007/BF01993288

PMid:1793036

22. Bergmans D, Bonten M, Gaillard C, Van Tiel F, Van der Geest S, Stobberingh E. In vitro antibacterial activity of sucralfate. Eur J Clin Microbiol Infect Dis. 1994;13(7):615-20. 10.1007/ BF01971318

\section{PMid:7805695}

23. Lyon CC, Stapleton M, Smith AJ, Griffiths CE, Beck MH. Topical sucralfate in the management of peristomal skin disease: an open study. Clin Exp Dermatol. 2000;25(8):458-588. 10.1046/j.1365-2230.2000.00711.x PMid:11167966

24. Moore OA, Smith LA, Campbell F, Seers K, McQuay HJ, Moore RA. Systematic review of the use of honey as a wound dressing. BMC Complement Altern Med. 2001;1(1):2. http:/l dx.doi.org/10.1186\%2F1472-6882-1-2

PMid:11405898

25. Wijesinghe M, Weatherall M, Perrin K, Beasley R. Honey in the treatment of burns: A systematic review and meta- analysis of its efficacy. N Z Med J. 2009;122(1295):47-60.

PMid:19648986

26. Storm-Versloot MN, Vos CG, Ubbink DT, Vermeulen H. Topical silver for preventing wound infection. Cochrane Database Syst Rev. 2010;3:CD006478. http://dx.doi.org/10.1002/14651858. CD006478.pub2 PMid:20238345

27. Jull $A B$, Walker N, Deshpande S. Honey as a topical treatment for wounds. Cochrane Database Syst Rev. 2013;3:CD005083. http://dx.doi.org/10.1002/14651858.CD005083.pub2 PMid:25742878

28. Lefevbre C, Eisinga A, McDonald S, Paul N. Enhancing access to reports of randomized trials published worldwide the contribution of EMBASE records to the cochrane central register of controlled trials (CENTRAL) in the cochrane library. Emerg Themes Epidemiol. 2008;5:13. http://dx.doi. org/10.1186/1742-7622-5-13

PMid:18826567

29. Higgins JPT, Green S, editors. Cochrane Handbook for Systematic Review of Interventions 5.1.0 The Cochrane Collaboration; 2011. Available from: http://www.handbook. cochrane.com [Last accessed on 2021 Jan 20].

30. Berger VW, Alperson SY. A general framework for the evaluation of clinical trial quality. Rev Recent Clin Trials 2009;4(2):79-88. 10.2174/157488709788186021 PMid:19463104

31. Banati A, Chowdhury SR, Mazumder S. Topical use of sucralfate cream in second and third degree burns. Burns. 2001;27(5):4659. http://doi.org/10.1016/s0305-4179(00)00165-0

32. Godhi AS, Ram P, Powar R. Efficacy of topical sucralfate versus silver sulfadiazine in the management of burns: A 1-year randomized controlled trial. J West Afr Coll Surg. 2017;7(1):57-70.

PMid:29951455

33. Koshariya M, Shitole A, Agarwal V, Dave S. Role of topical sucralfate in healing burn wounds. Int Surg J. 2018;5(9):2995-3001.

34. World Health Organization. Burns Fact Sheet No. 365. Geneva: World Health Organization; 2014.

35. Karayil S, Deshpande SD, Koppikar GV. Effect of honey on multidrug resistant organisms and its synergistic action with three common antibiotics. Postgrad Med. 1998;44(4):93-6. PMid:10703581

36. Lansdown A, Silver I. Its antibacterial properties and mechanism of action. J Wound Care. 2002;11(4):125-30. http://dx.doi. org/10.12968/jowc.2002.11.4.26389 PMid:11998592

37. Dai T, Huang YY, Sharma SK, Hashmi JT, Kurup DB, Hamblin MR. Topical antimicrobials for burn wound infections. Recent Pat Antiinfect Drug Discov. 2010;5(2):124-51. http:// dx.doi.org/10.2174/157489110791233522 PMid:20429870

38. Wasiak J, Cleland H. Burns (minor thermal). BMJ Clin Evid 2009;10:1903.

PMid:26173045

39. Lee AR, Leem H, Lee J, Chan Park K. Reversal of silver sulfadiazine-impaired wound healing by epidermal growth factor. Biomaterials. 2005;26(22):4670-6. http://dx.doi.org/10.1016/j. biomaterials.2004.11.041

PMid: 15722137

40. Wasiak J, Cleland H, Campbell F. Dressings for superficial and partial thickness burns. Cochrane Database Syst Rev. 2013;2013(3):CD002106. 10.1002/14651858.CD002106.pub4 


\section{PMid:23543513}

41. Maghsoudi $\mathrm{H}$, Monshizadeh S, Mesgari M. A comparative study of the burn wound healing properties of saline- soaked dressing and silver sulfadiazine in rats. Indian J Surg. 2011;73(1):24-7. http://dx.doi.org/10.1007/s12262-010-0169-2

\section{PMid:22211033}

42. Rosen J, Landriscina A, Kutner A, Adler BL, Krausz AE, Nosanchuk JD, et al. Silver sulfadiazine retards wound healing in mice via alterations in cytokine expression. J Invest Dermatol. 2015;135(5):1459-62. http://dx.doi.org/10.1038/jid.2015.21 PMid:25625423

43. Aziz Z, Abu SF, Chong NJ. A systematic review of silvercontaining dressings and topical silver agents (used with dressings) for burn wounds. Burns. 2012;38(3):307-18. http:// dx.doi.org/10.1016/j.burns.2011.09.020

PMid:22030441

44. Koller J. Topical treatment of partial thickness burns by silver sulfadiazine plus hyaluronic acid compared to silver sulfadiazine alone: A double-blind, clinical study. Drug Exp Clin Res. 2004;30(5-6):183-90.

PMid:15700744

45. Hollander D, Tarnawski A. The protective and therapeutic mechanisms of sucralfate. Scand J Gastroenterol. 1990;173:15. 10.3109/00365529009091917

PMid:2190304 